Table 1. Statistics of debarked trees in a $13 \mathrm{~km} \times 10 \mathrm{~m}(=13 \mathrm{ha})$ size strip of forest in Mt. Abu Sanctuary

\section{FOOD HABITS OF HANUMAN LANGUR (SEMNOPITHECUS ENTELLUS) DURING DRY SEASON AT MOUNT ABU WILDLIFE SANCTUARY}

\author{
Satish Kumar Sharma \\ Range Forest Officer(Wildlife), Phulwari Sanctuary, Kotra, District \\ Udaipur, Rajasthan 307025, India.
}

As a member of Aravalli Eco-working Group, I was studying the fauna and flora of Mt. Abu Wildlife Sanctuary in Sirohi District of Rajasthan during April, 2001. I came across many troops of Hanuman Langurs (Semnopithecus entellus) along the road from Abu Taleti to Mt. Abu Town, which were engaged in devouring the bark of a variety of trees. Downhill from Abu Taleti to Forest Point, I noticed as many as 60 heavily debarked trees in a $13 \mathrm{~km}$ long and nearly $10 \mathrm{~m}$ wide forest strip along the road (Table 1). Although debarking was visible on either sides of the road, much damage was noticed towards downhill side because a parapet wall provided vantage advantage. Trees present very near to the parapet wall were badly affected than those situated away from it.

Mt. Abu and whole of Rajasthan faced severe drought in consecutive years (1998 to 2000). Due to scarcity of rainfall, the foothills and middle slopes of Mt. Abu are bone dry. Though it rains generally in the month of April during a year with good rains, this year it rained in March 2001. When I visited this area in the month of Febuary, 2001, the greenery was quite good and bark was not in the menu of the Langurs. Vegetation between Abu Taleti and Forest Point became completely leafless during March, however Capparia sepearia and Ficus glomerata were still bearing green leaves. Since upper reaches of Mt. Abu bears semi-evergreen forests, that part was green as usual. The reason for the confinement of the langur troops in this leafless zone may be due to either (a) the langurs of foothill and middle slopes were disinterested in leaving their home range, or, (b) the langurs of upper reaches did not allow their entry.

Langurs of upper zone had a folivorous diet because it was easily available to them and debarking in this zone did not occur. Mathur and Manohar (1987) have given a list of 25 plant species from Jaipur zone of Rajasthan used as food by langurs. According to them, langurs take only the bark of Psidium guajava as food. Many workers like Moore (1985), Mathur and Bhatnagar (1993) have studied the dietary habits of P. entelleus

\begin{tabular}{lcc}
\hline Affected tree species & Number debarked & Nature of damage \\
\hline Boswellia serrata & 18 & $\mathrm{M}$ \\
Lannea coromandelica & 24 & $\mathrm{M}$ \\
Ficus glomerata & 1 & $\mathrm{LM}$ \\
Cassia fistula & 1 & $\mathrm{LM}$ \\
Mitragyna parviflora & 1 & $\mathrm{LM}$ \\
Erythrina suberosa & 1 & $\mathrm{LM}$ \\
Sterculia urens & 1 & $\mathrm{LM}$ \\
Anogeissus latifolia & 13 & $\mathrm{LM}$ \\
\hline
\end{tabular}

*M - Massive; LM - Less Massive

but no one has recorded bark as their main food.

Due to an acute scarcity of green foliage in the lower zone of Mt. Abu area, I observed langurs taking fresh bark of trees as 'famine-food' to overcome food scarcity. This phenomenon of wildlife feeding on such marginal food is not unique to this part of Rajasthan. Elsewhere in Rajasthan cervids like Chital and Sambar in Sariska Tiger Reserve survive by feeding on leaflitter in peak summer months (N.V.K. Ashraf, pers. comm.). Porcupines in Sariska Tiger Reserve survive mostly by debarking trees during periods of food shortage (Sharma, 1989).

While surveying the forest area of Kumbhalgarh Wildlife Sanctuary in Pali and Udaipur Districts on 17 May 2001, the langurs were seen to debark in this Sanctuary also. Besides Boswellia serrata, Ficus glomerata and Anogeissus latifolia, they were also seen debarking Albizia odoratissima and Tamarindus indicus.

Debarking is of two types.

Total debarking: The vertical main trunks of trees and vertical extremities of branches is debarked. In this case, the bark is removed from all sides of the trunk. Ocassionally few patches remain intact at random intervals.

Upper surface debarking: This type was seen in the horizontal branches and debarking was limited to the upper surface.

\section{Acknowledgements}

Author is very grateful to Sh. Rahul Bhatanagar, Sh. T.C. Verma, Sh. V.S. Rana, Sh. Bhopal Singh and Sh. Karan Singh for providing facilities.

\section{References}

Mathur, R. and P.S. Bhatnagar (1993). Study of activity pattern in Presbytis entellus at Ambagarh Reserve Forest, Jaipur. Journal of the Bombay Natural History Society 90(3): 495-497.

Mathur, R. and B.R. Manohar (1987). Group number and composition of Hanuman Langurs (Presbytis entellus) in Jaipur, India. Journal of the Bombay Natural History Society 84(1): 193-199.

Moore, J. (1985). Insectivory by Grey Langurs. Journal of the Bombay Natural History Society 87(1): 38-44.

Sharma, D. (1989). Spatial and temporal patterns in debarking by Crested Porcupine in Sariska Tiger Reserve. M.Sc. Dissertation. Saurashtra University. 